\title{
ANTARCTIC ICEBERG DISTRIBUTION AND DISSOLUTION
}

\author{
By T. C. HAMLEY \\ (Antarctic Division, Channel Highway, Kingston, Tasmania 7150, Australia) \\ and W. F. BUDD \\ (Meteorology Department, University of Melbourne, Parkville, Victoria 3052, Australia)
}

\begin{abstract}
Shipboard observations (in accordance with Norsk Polar-Institutt guidelines) from 6 years of Australian National Antarctic Research Expeditions (ANARE) voyages have provided data giving a detailed knowledge of iceberg sizes and concentrations in the Southern Ocean between long. $60^{\circ}$ and $140^{\circ} \mathrm{E}$. The resulting size-frequency distributions are examined in conjunction with a knowledge of water movement along known drift tracks in a selected study area (between lat. $59^{\circ}$ and $64^{\circ} \mathrm{S}$., and long. $90^{\circ}$ and $120^{\circ} \mathrm{E}$.) to determine iceberg-dissolution rates. The "median life" (before breaking) of icebergs less than $1000 \mathrm{~m}$ in horizontal dimension is estimated to be $0.2 \mathrm{a}$, which is significantly lower than was previously thought. The mean melt rate is estimated to be $0.12 \mathrm{~m} \mathrm{~d}^{-1}$, which agrees broadly with previous laboratory studies. The relative contributions of melt, calving, and breakage, plus the enhancement effect of roll-over, are examined in estimating the natural dissolution rate. Breakage appears to be the dominant mechanism for larger icebergs with melt and calving able to explain the disappearance of icebergs in the smallest categories only (within the mean "median-life" period). Examination of the historical records of Captain Cook indicates that iceberg concentrations, as well as the northerly extent in this region 200 years ago, were compatible with the present data.
\end{abstract}

RÉSUMÉ. Répartition et disparition des icebergs en Antarctique. Des observations à partir de bâteaux (suivant le procédé du Norsk Polar-Institutt) effectuées pendant 6 années au cours des voyages des Australian National Antarctic Research Expeditions (ANARE), ont donné des informations qui fournissent une connaissance détaillée de la taille et de la concentration des icebergs dans le sud de l'océan entre $60^{\circ}$ et $140^{\circ}$ de longitude Est. Les résultats des répartitions de fréquence en tailles sont examinés avec la connaissance des mouvements de l'eau suivant des trajets connus dans une zone d'étude sélectionnée (entre les latitudes $59^{\circ}$ et $64^{\circ}$ Sud et les longitudes $90^{\circ}$ et $120^{\circ}$ Est), pour la détermination de la vitesse de disparition des icebergs. La "durée de vie moyenne" (avant leur éclatement) d'icebergs plus petits que $1000 \mathrm{~m}$ en dimension horizontale est estimée à 0,2 an, ce qui est significativement inférieur aux idées habituelles. La vitesse de fonte est estimée à $0,12 \mathrm{~m} \mathrm{jour}^{-1}$, ce qui concorde globalement avec les études

\section{INTRODUCTION}

The realization more than a decade ago (Weeks and Campbell, 1973) that Antarctic icebergs were a potential fresh-water resource triggered a world-wide expansion of interest in iceberg research amongst scientists, environmentalists, engineers, and entrepeneurs.

The amount of scientific literature now available on icebergs is extensive. Two international conferences have canvassed the topic of iceberg utilization in depth (Husseiny, 1978; International Glaciological Society, 1980) as antérieures de laboratoire. Les contributions relatives de la fonte, du vêlage, du débitage, y compris l'augmentation due au roulis, sont examinées dans l'estimation de la vitesse de disparition naturelle. Le débitage apparait être le mécanisme prépondérant pour les grands icebergs tandis que la fonte et le vêlage sont plus aptes à rendre compte de la disparition des icebergs de taille la plus faible (en terme de durée de vie moyenne"). Un examen des relations historiques du capitaine Cook indique que la concentration des icebergs, de même que leur extention septentrionale dans cette région, il y a deux siècles, sont compatibles avec les données actuelles.

ZUSAMMENFASSUNG. Verteilung und Auflösung von Eisbergen in der Antarktis. Schiffsbeobachtungen (nach den Richtlinien des Norsk Polar-Institutt) aus Fahrten der Australian National Antarctic Research Expeditions (ANARE) über 6 Jahre lieferten Daten für eine genaue Kenntnis der Eisberggrössen und -konzentrationen im Südozean zwischen $60^{\circ}$ und $140^{\circ}$ ostlicher Länge. Die daraus abgeleiteten Verteilungen für Grösse und Häufigkeit werden in Verbindung mit Daten über die Wasserbewegung entlang bekannter Driftlinien in einem ausgewăhlten Studiengebiet (zwischen $59^{\circ}$ bis $64^{\circ}$ südlicher Breite und $90^{\circ}$ bis $120^{\circ}$ östlicher Länge) zur Bestimmung der Auflösungsgeschwindigkeit von Eisbergen untersucht. Die "mittlere Lebenszeit" (vor dem Zerbrechen) von Eisbergen mit horizontalen Dimensionen von weniger als $1000 \mathrm{~m}$ wird auf 0,2 Jahre geschätzt, was weit unter dem bisher angenommenen Wert liegt. Die mittlere Abschmelzrate wird auf $0,12 \mathrm{~m}$ pro Tag geschätzt, was weitgehend mit früheren Laboruntersuchungen übereinstimmt. Die relativen Anteile des Schmelzens, Kalbens und Abbrechens einschliesslich der Verstärkungseffekte des Kenterns werden unter Abschätzung der natürlichen Auflösungsrate untersucht. Abbruch scheint der vorherrschende Mechanismus für grössere Eisberge zu sein; Schmelzen und Kalben hingegen können nur zur Erklärung des Verschwindens von Eisbergen der kleinsten Kategorien herangezogen werden (innerhalb der "mittleren Lebenszeit"). Eine Prüfung der historischen Aufzeichnungen von Kapitän Cook lässt erkennen, dass die Eisbergkonzentrationen und ihr Vordringen nach Norden in diesem Gebiet vor 200 Jahren dem derzeitigen Zustand vergleichbar waren.

well as a separate international symposium dealing only with the practical and theoretical problems associated with iceberg drift (Russell, 1979). Major sections of texts have also been devoted to icebergs (Robe, 1980; Keys, 1984). Since May 1982 an iceberg newsletter (Iceberg Research) has been widely distributed by the Scott Polar Research Institute, Cambridge.

Reliable estimates of Antarctic iceberg life expectancy are fundamental to the assessment of the viability of towing schemes involving unprotected icebergs. Schwerdtfeger (1979) based a comprehensive review of icebergs and their uses on 
an acknowledged "... paucity of information on the natural breakup of icebergs".

Glaciologists have recently attempted to determine the state of mass balance of the Antarctic ice sheet upon data from iceberg observations (Orheim, 1985). Knowledge of iceberg-dissolution rates has also been an important consideration in the marine studies of environmentalists (Schwerdtfeger, 1978; Shulenberger, 1983) and oceanographers studying polar currents (Swithinbank and others, 1977; Tchernia and Jeannin, 1984).

Icebergs in the ocean undergo a wide range of different processes resulting in a decrease of ice volume with time. These processes include melt, breakage, calving, and other forms of ablation. The general term "dissolution" is used here to cover the totality of these processes contributing to the changes in iceberg sizes, numbers, and ice volume with time.

In this paper, life expectancy is referred to in terms of a "median life", where the "median life" is defined by the time taken for the icebergs in a particular size group to be reduced to half their number by breakage into smaller sizes.

Considerable knowledge and experience of iceberg mechanics has been gained in Arctic regions largely as a result of the hazards which icebergs pose to shipping and the oil industry (Bruneau and others, 1978; POAC 79, 1979). However, most of this knowledge is not directly applicable to the Antarctic region for a number of reasons. Antarctic icebergs may be more than an order of magnitude larger in mass and horizontal dimensions. They are also, generally, much thicker and colder. Antarctic icebergs are rarely sighted north of the cool waters encircled by the Antarctic Convergence (approximately lat. $51^{\circ} \mathrm{S}$.), in contrast to Arctic icebergs which, for example, are commonly observed in the Labrador Current close to the coast of Newfoundland. Thus, iceberg-dissolution rates observed in the Arctic (Robe and others, 1977) should be interpreted in regard to their in-situ conditions which might be quite different from those in the Antarctic.

Satellite surveillance would seem to be the most effective method of monitoring iceberg movement and decay. Vinje (1980) and Tchernia and Jeannin (1984) have studied polar ocean currents by placing radio beacons on tabular Antarctic icebergs and monitoring their movement via satellite transmissions. Unfortunately, however, no group has so far been able to re-measure carefully the icebergs which have been tracked and therefore determine their rates of change. Until such a re-measurement programme is undertaken, the distinction between melt, calving, and breakage (and the enhancement effect of roll-over) will remain somewhat obscure but can be examined in a statistical way by the type of analysis described in this paper.

Swithinbank and others (1977) and McClain (1978) have used satellite imagery to plot drift tracks; however, this technique while excellent for identifying gyres and general current movement is only suitable for tracking gigantic icebergs. Some of the problems associated with using satellite pictures are: obscuration by cloud, lack of solar illumination during winter, limited resolution and coverage, difficulty distinguishing between icebergs and sea ice, and difficulty recognizing the same iceberg again.

In short, the immediate answers to the question of iceberg-dissolution rates may still best be found from the now extensive size and number data from shipboard observations.

\section{THE SPATIAL DISTRIBUTION OF ANTARCTIC
ICEBERGS}

A spatial distribution of Antarctic icebergs from historical sightings has been compiled for the entire Southern Ocean in map form by Nazarov (1962). Budd and others (1980) added to this the contours of mean ocean temperatures at a $200 \mathrm{~m}$ depth as given by Gordon and Goldberg (1970). Burrows (1976) tabulated historical sightings in an endeavour to correlate high concentrations of icebergs with Southern Hemisphere climatic events; however (like Nazarov's compilation), the lack of detail concerning sizes and numbers precludes an estimate of dissolution rates.

Romanov (1973) was able to establish a relationship between iceberg sizes and latitude. The resulting frequency distributions were then analysed by Morgan and Budd (1978), along with Australian National Antarctic Research Expeditions (ANARE) data, to provide one of the first estimates of melt and dissolution rates.

Dmitrash (1971) fitted an empirical (exponential) curve to latitudinal profiles obtained from radar observations within the sector of the Southern Ocean between long. $10^{\circ}$ and $20^{\circ} \mathrm{E}$. He showed that in this region there was a characteristic decrease in iceberg numbers with increasing distance from the coast, although further north a second maximum occurred due to the input of icebergs (from the Antarctic Peninsula) floating eastward in the Antarctic Circum-polar Current.

Neshyba (1980) used a composite of iceberg distributions to demonstrate the suitability of fitting a theoretical Raleigh distribution, and concluded by suggesting boundary conditions which might form the basis of a simple model of steady-state size distributions. The model conditions suggested by Neshyba included: a side-wall wastage rate of $100 \mathrm{~m} \mathrm{a}^{-1}$, an average iceberg draft of $200 \mathrm{~m}$, iceberg fracturing into two equal parts, and an initial distribution of sizes with an assumed length to breadth ratio of 1.6.

Amongst these compilations and distributions, however, none shows enough detail for reliable dissolution analysis.

\section{ANARE SHIPBOARD OBSERVATIONS}

ANARE have been collecting data on iceberg observations since 1948 but started a more extensive programme from $1977-78$.

In 1982-83 the ANARE iceberg observation programme adopted guidelines originating from the Norsk Polar-Institutt (on the collection of iceberg data) and began classifying iceberg sightings according to these standardized size categories. Width estimates (and in some cases, height, length, and breadth) were usually made from the visual sightings of an observer standing on the ship's bridge. In some cases, a sextant was used to measure a subtended angle (in conjunction with radar distance) to calculate accurately the width and freeboard height. In general, however, the accuracy of these observations is indeterminate and obviously variable depending on the diligence of individual observers. Data presented in this paper represent observations from all ANARE voyages since 1979 covering a longitude range from approximately $60^{\circ}$ to $140^{\circ} \mathrm{E}$.

Budd and others (1980) used data to 1979 to determine the distribution of both concentration and size of icebergs to examine the process of iceberg dissolution. This paper therefore extends the work of Morgan and Budd (1978) and Budd and others (1980), and establishes new estimates of iceberg median life and dissolution rate based on the more extensive data now available.

\section{SIZE DISTRIBUTIONS (LONG. $60^{\circ}$ to $130^{\circ} \mathrm{E}$.)}

The determination of iceberg concentrations has been carried out for the following size categories (i.e. the general horizontal dimension as viewed from the ship): $10-50 \mathrm{~m}$, $50-200 \mathrm{~m}, 200-500 \mathrm{~m}, 500-1000 \mathrm{~m}$, and for icebergs over $1000 \mathrm{~m}$. This general horizontal dimension will hereafter be referred to as the mean width $(w)$, to distinguish it from the length $(l)$ and breadth $(b)$ of an approximately rectangular representation of an iceberg when the shape is known.

Iceberg concentrations refer to the number one would expect to see within a 12 nautical mile (n.m.) $(22 \mathrm{~km})$ radius of the ship.

Figures 1 and 2 represent the concentrations of icebergs along cross-sections of longitude $10^{\circ}$ wide (from
long. $60^{\circ}$ to $130^{\circ} \mathrm{E}$.) and in latitudinal increments of $1^{\circ}$, from lat. $56^{\circ}$ to $66^{\circ} \mathrm{S}$. Although iceberg observations have been gathered to the east of long. $130^{\circ} \mathrm{E}$., iceberg concentrations there are comparatively small and the data are irregular to the east of long. $135^{\circ} \mathbf{E}$. Therefore, no distribution is shown for the longitude range $130^{\circ}$ to $140^{\circ} \mathrm{E}$. The profiles for all size categories (including the total iceberg concentration) show interesting detail with consistent trends 


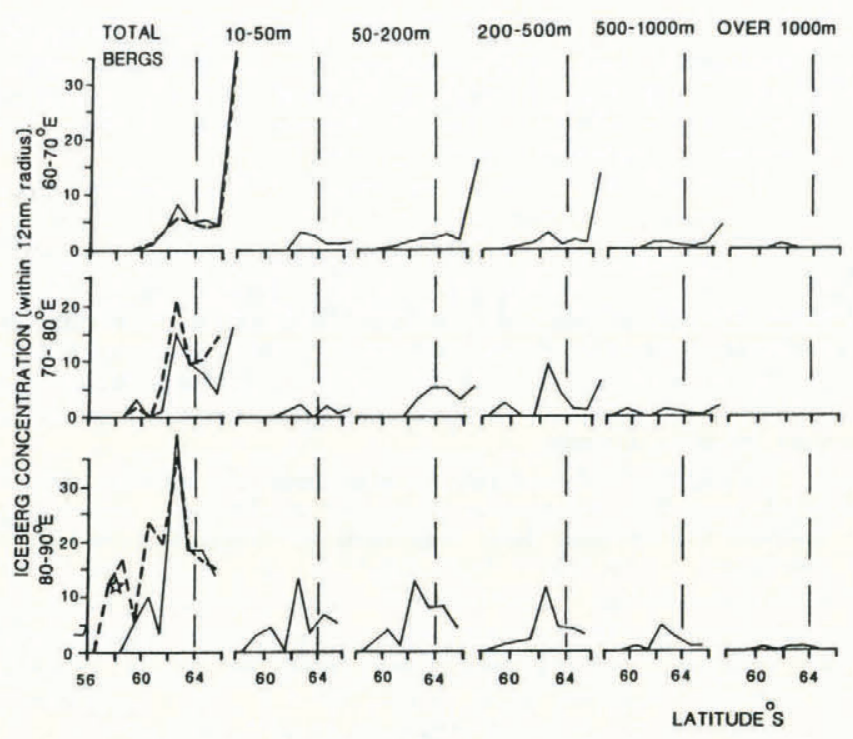

Fig. 1. Iceberg size-concentration profiles for latitudes between $56^{\circ}$ and $66^{\circ} \mathrm{S}$., and long. $60^{\circ}-90^{\circ} \mathrm{E}$. (note that concentration represents the number of icebergs within $a$ 12 nautical mile radius). A thin dashed line at lat. $64^{\circ} \mathrm{S}$. is in general agreement with the suggested latitude of the Antarctic Divergence where a local minimum in iceberg concentrations is apparent. The heavy dashed line represents total iceberg concentration which includes records where only a total was given and the size distributions are unknown. The star represents iceberg concentration as observed by Captain Cook in 1773.

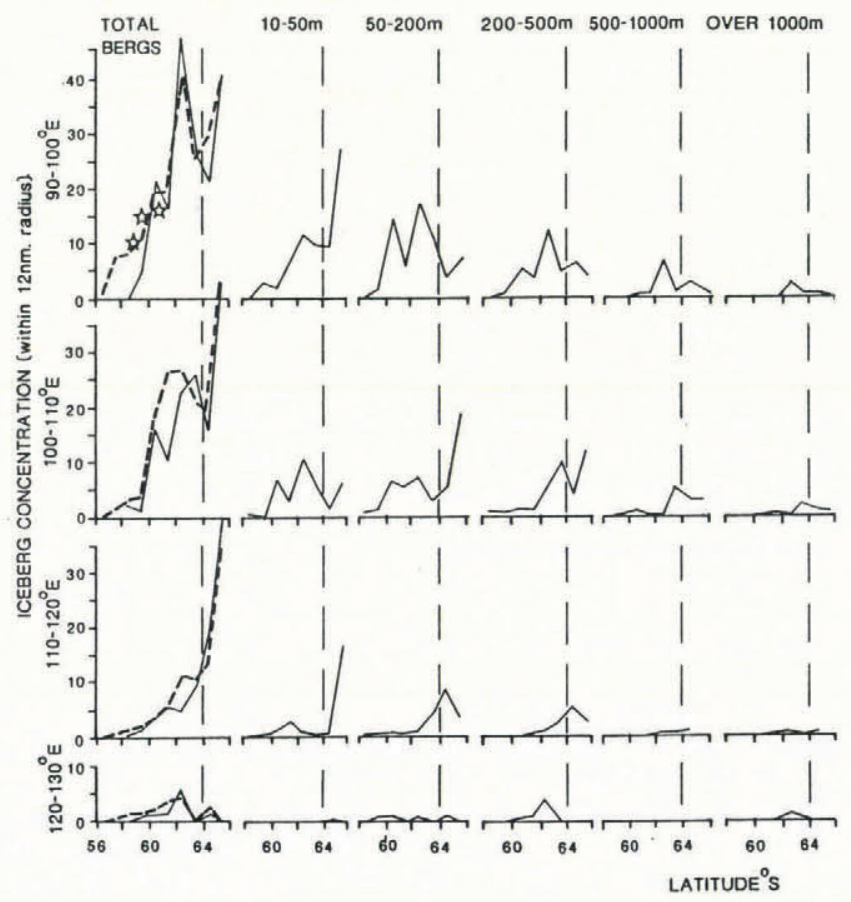

Fig. 2. As described in Figure 1, for long. $90^{\circ}-130^{\circ} \mathrm{E}$.

which were not apparent in the earlier profiles of Shilnikov (1969) or Budd and others (1980).

In Figure 2, total iceberg concentrations increase from less than 1 per $12 \mathrm{n} . \mathrm{m}$. radius at lat. $59^{\circ} \mathrm{S}$. to a peak near lat. $63^{\circ} \mathrm{S}$. A noticeable drop in iceberg concentrations further south is evident before they increase again towards the coast.

The decrease in the concentration of icebergs from near lat. $63^{\circ}$ to $64^{\circ} \mathrm{S}$. is associated with the Antarctic surface-water divergence zone near the edge of the continental shelf in this region of East Antarctica. Icebergs and currents moving westward along the continental shelf (with

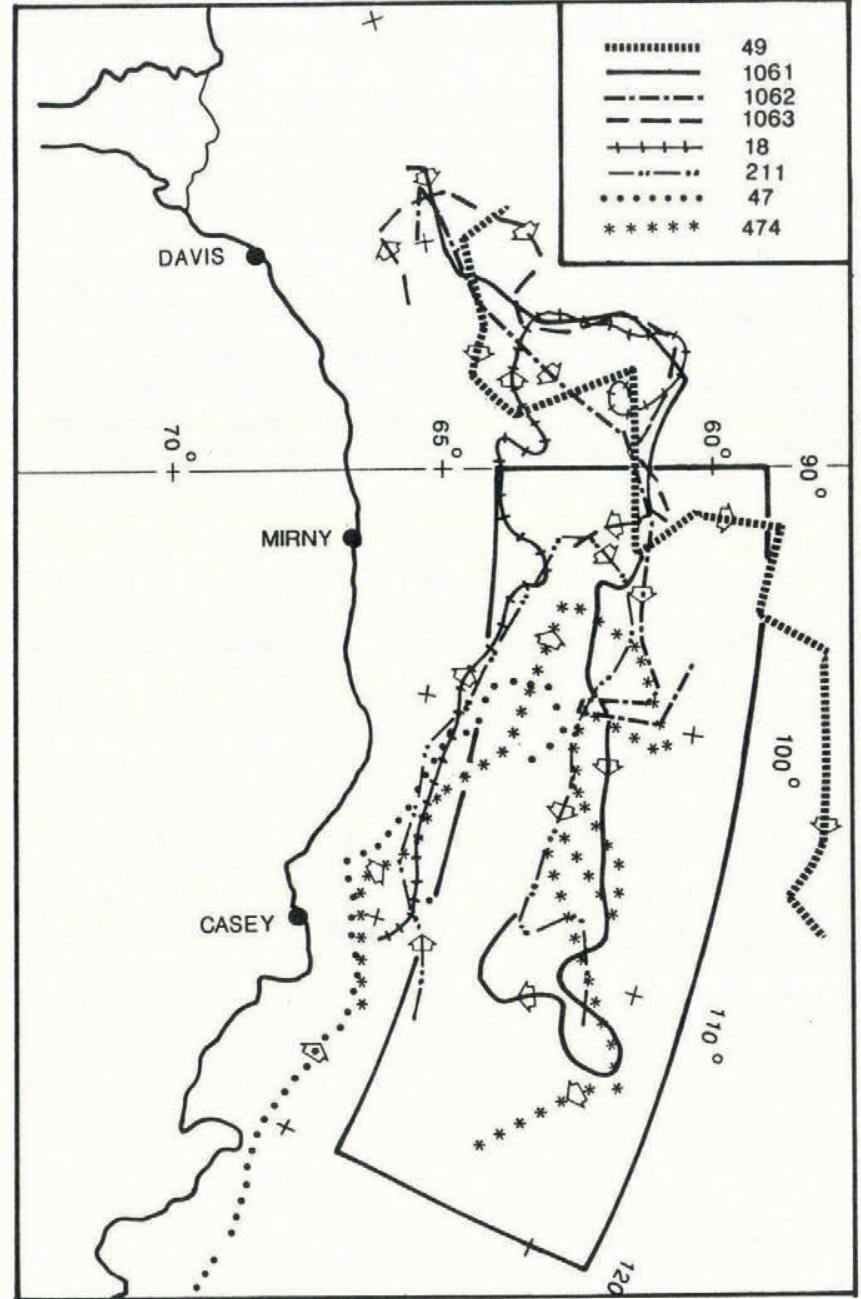

Fig. 3. Drift tracks of Antarctic icebergs from Tchernia and Jeannin (1984). Iceberg tracks have been redrawn in a simplified form and serve to illustrate the general patterns of surface-water movement in this region of East Antarctica. Several features are clearly evident as follows: the East Wind Drift along the continental shelf, the permanent recurvature near long. $90^{\circ} \mathrm{E}$., and the Antarctic Circum-polar Current north of the continental shelf. Iceberg tracks between long. $80^{\circ}$ and $90^{\circ} \mathrm{E}$. (to the north-east of Prydz Bay) are rather erratic although the detail is not shown in this representation. Arrows indicate the direction of travel.

the East Wind Drift current) are clearly separated from icebergs and currents moving eastward in the Circum-polar Current of the Southern Ocean. Figure 3 (after Tchernia and Jeannin, 1984) shows the pattern of water movement.

Looking at the overall numbers from one longitude band to another (Fig. 2), it is clear that the concentration of icebergs north of lat. $64^{\circ} \mathrm{S}$. is decreasing evenly to the east of long. $90^{\circ} \mathrm{E}$. The concentration of icebergs shows a maximum near long. $90^{\circ} \mathrm{E}$. just eastward of the KerguelenGaussberg Ridge, which also corresponds to an interconnection region between easterly and westerly flow studied by Tchernia and Jeannin (1980). The more northerly extent of icebergs in the regions long. $80-90^{\circ} \mathrm{E}$. and $90-100^{\circ} \mathrm{E}$. (heavy dashed line in Figures 1 and 2) is apparent, and corresponds closely to the more northerly extent of the maximum average sea-ice boundary over the same time interval, 1979-83 (Fig. 4). In Figures 1 and 2, the solid line (for the total iceberg concentration) represents only the records where the total of observed icebergs matched the sum of those distributed into size categories. However, many observations were made by radar in either poor or zero visibility, where sizing was not possible. The heavy dashed 


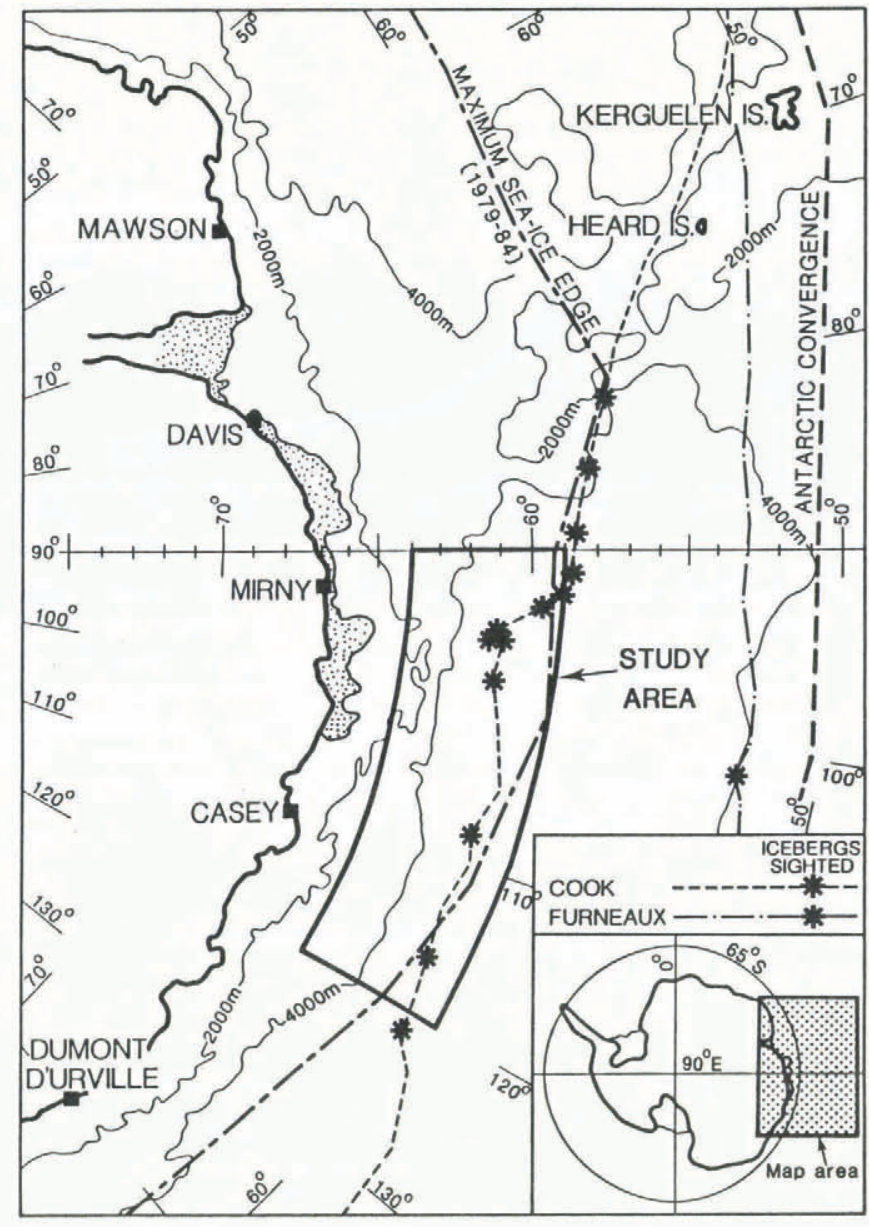

Fig. 4. Iceberg dissolution analysis study area, between lat. $59^{\circ}$ and $64^{\circ} \mathrm{S}$. and long. $90^{\circ}$ to $120^{\circ} \mathrm{E}$. Bathymetric contours have been taken from USSR (1974): bathymetric map of Antarctica. Also shown is the maximum average sea-ice extent from 1979 to 1984 (updated from Jacka (1983)) and the approximate position of the Antarctic Convergence. The second voyage of Captain Cook in the year 1773 (HMS Resolution and sister ship HMS Adventure captained by Tobias Furneaux) is also marked and shows the noon-day position of days when iceberg sightings were recorded.

line therefore includes all observation totals and is more reliable in indicating the total concentration of icebergs within a $12 \mathrm{n}, \mathrm{m}$. radius.

\section{ICEBERG-DISSOLUTION RATES}

The uniform decrease in iceberg concentrations to the east of long. $90^{\circ} \mathrm{E}$. (apparent in Figure 2) led to a distribution along a known drift-track band (shown in Figures 3 and 4). It is assumed that all icebergs which enter the study area between long. $90^{\circ}$ and $100^{\circ} \mathrm{E}$. move to the east in the Circum-polar Current between lat. $59^{\circ}$ and $64^{\circ} \mathrm{S}$. without leaving the northern or southern boundaries. It is also assumed that iceberg records obtained from the six summer seasons of ANARE observations represent a steady-state distribution in both time and space. A representative summer water temperature for the upper $200 \mathrm{~m}$ of $+1^{\circ} \mathrm{C}$ has been adopted for this region (refer to figure 12 of Budd and others (1980)).

The study area was designated to be between lat. $59^{\circ}$ and $64^{\circ} \mathrm{S}$. and in $10^{\circ}$ sectors of longitudge from $90^{\circ}$ to $120^{\circ} \mathrm{E}$., as shown in Figure 4. Reference to the iceberg tracks in Figure 3 confirms the circum-polar flow pattern of the integrated ocean current and hence the general iceberg movement. The choice of a northern boundary at lat. $59^{\circ} \mathrm{S}$. ensures that the overwhelming majority of the more northerly icebergs moving in the Circum-polar Current will remain within the study area for dissolution analysis. Lat. $64^{\circ} \mathrm{S}$. was chosen as the southern boundary, since it corresponds approximately to the Antarctic Divergence where a local minimum in iceberg numbers is observed. Similarly, this ensures the repeated catchment of the overwhelming majority of the more southerly icebergs moving in the Circum-polar Current.

Longitudinal sectors were chosen in $10^{\circ}$ segments to smooth out variability. The western boundary (long. $90^{\circ} \mathrm{E}$.) corresponds to a regional maximum in iceberg concentrations and represents the zone of major inflow of icebergs to the study area (see Fig. 3). The eastern boundary (long. $120^{\circ} \mathrm{E}$.) was chosen because, further to the east, the general current regime seems to shift slightly to the south in accordance with the $4000 \mathrm{~m}$ bathymetric contour (Fig. 4; derived from USSR (1974)) and because of the fact that ANARE iceberg observations are relatively few and therefore slightly less reliable to the east of long. $125^{\circ} \mathrm{E}$. In fact, the observations of Keys and Williams (1984), and Hamley (personal observation), confirm that by long. $140^{\circ} \mathrm{E}$. iceberg concentrations have dropped to about zero in the latitude band covered by the study area.

Schwerdtfeger (1979) categorized the individual dissolution processes of icebergs as follows:

"1. Turbulent forced convective ablation of the bottom and immersed areas of the sides.

2. Buoyancy induced natural convective ablation along the sides.

3. Undercutting of the sides by wave action and subsequent calving of sections above the waterline.

4. Differential melting along cracks leading to further calving.

5. Possible fracturing of the iceberg caused by thermal stresses, especially in warmer waters.

6. Splitting of large icebergs which may be caused by ocean swell of sufficient amplitude or wavelength related to the dimensions of individual icebergs."

For the purpose of this paper these processes could be generalized within three groups as follows: processes 1 and 2 could be regarded as melt, processes 3 and 4 as calving, and processes 5 and 6 as breakage. The task then is to distinguish between the relative contribution of melt, calving, breakage, and the enhancement effect of roll-over in the natural dissolution of Antarctic icebergs.

To determine the dissolution rate, one also requires an estimate of the average speed of icebergs through the study area. The most reliable estimates of drift speeds are revealed by the iceberg drift tracks (Fig. 3; after Tchernia and Jeannin, 1984). Icebergs Nos. 1061, 1062, 211, and 474 are all relevant. In this paper an average measured speed of $5.0 \mathrm{~km} / \mathrm{d}$ is used to represent the study area only. Note that this is only about half of the day-to-day (or short-term) speed typically quoted by Tchernia and Jeannin (1984). Probably the best estimate of straight-line speed is given by iceberg 1061 which, over part of its track at an approximate latitude of $61^{\circ} \mathrm{S}$., travelled approximately $27^{\circ}$ of longitude $(1461 \mathrm{~km})$ in $184 \mathrm{~d} \approx 7.94 \mathrm{~km} / \mathrm{d}$. However, this should be considered a maximum speed because icebergs frequently become locked in large-scale eddy currents and may spend several months gyrating in a localized region without making progress in the general flow direction (e.g. iceberg 474). Now, $10^{\circ}$ longitude at a mean latitude of $61.5^{\circ} \mathrm{S}$. is $532.6 \mathrm{~km}$. Therefore, the mean residence time per $10^{\circ}$ longitude in this region is taken as $107 \mathrm{~d}$ or 0.29 a.

In Figure 5, clear-cut trends are apparent between the concentrations of icebergs and longitude, for the latitude band between $59^{\circ}$ and $64^{\circ} \mathrm{S}$. Between long. $60^{\circ}$ and $90^{\circ} \mathrm{E}$. iceberg concentrations increase uniformly in all size categories. Reference to figure 10 of Smith and others (1985) and also the drifting-buoy tracks of Allison (personal communication) show an ocean-circulation pattern in the Prydz Bay area (between long. $70^{\circ}$ and $80^{\circ} \mathrm{E}$.) which would contribute large numbers of icebergs to explain the increasing numbers of icebergs between long. $60^{\circ}$ and $90^{\circ} \mathrm{E}$. Added to this is the effect of the permanent recurvature near long. $90^{\circ} \mathrm{E}$. (Tchernia and Jeannin, 1980) where large numbers of icebergs moving westward over or near the edge 

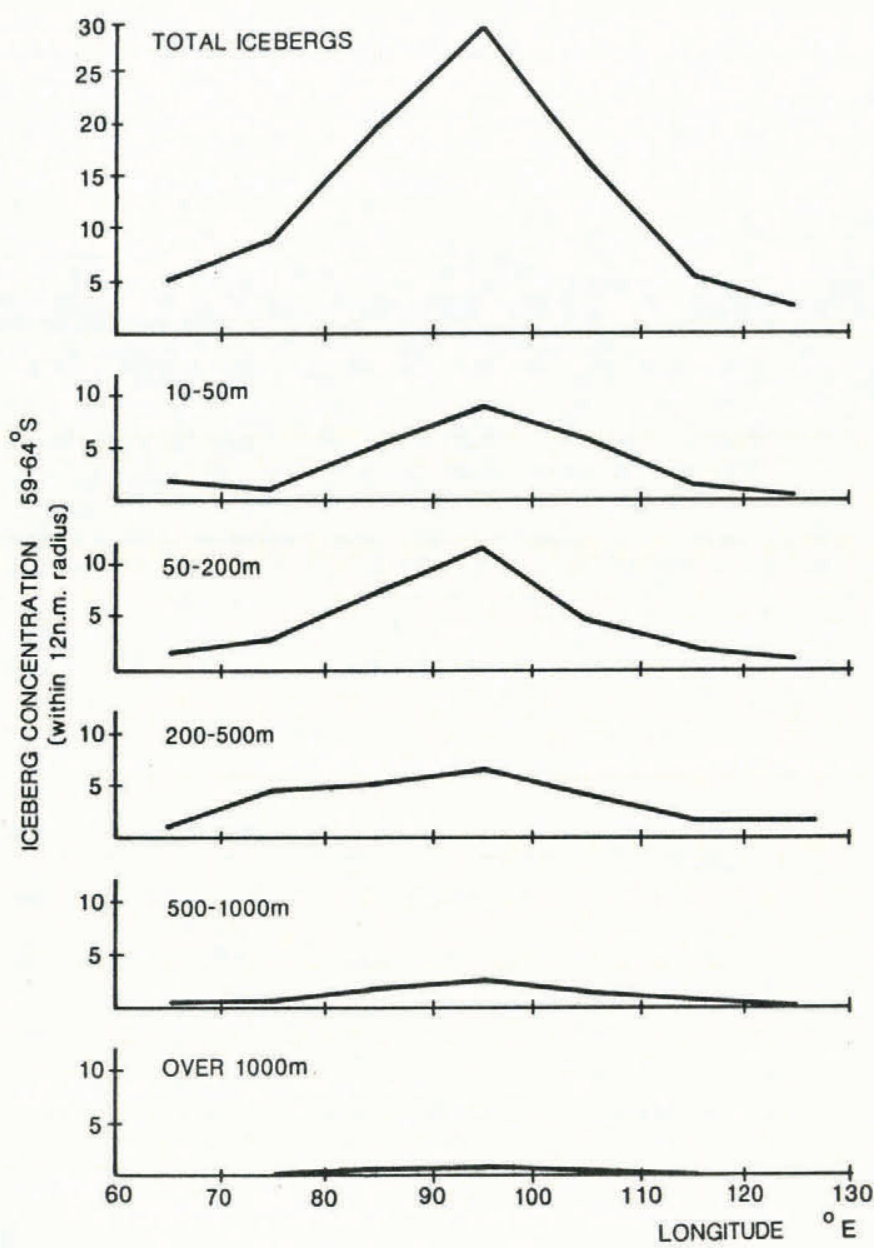

Fig. 5. Iceberg concentration (i.e. number within 12 nautical mile radius) cross-section for the latitude band between $59^{\circ}$ and $64^{\circ} \mathrm{S}$., from long. $60^{\circ}$ to $130^{\circ} \mathrm{E}$. These cross-sections show an increasing concentration of icebergs in all size categories from long. $60^{\circ}$ to $95^{\circ} \mathrm{E}$., and then $a$ uniform decrease in iceberg concentration further to the east.

of the continental shelf have been observed to move northward and then head east again with the Antarctic Circumpolar Current.

To the east of long. $90^{\circ} \mathrm{E}$., iceberg concentrations decrease uniformly in all size categories. It is clear from the melt-rate estimates of Russell-Head (1980) $\left(0.1 \mathrm{~m} \mathrm{~d}^{-1}\right.$ at $\left.+1{ }^{\circ} \mathrm{C}\right)$ and Budd and others (1980) $\left(0.1 \mathrm{~m} \mathrm{~d}^{-1}\right.$ at $\left.+1^{\circ} \mathrm{C}\right)$ that melting alone, even if it were considerably higher than these estimates, could not account for the decreasing number of icebergs in larger size categories but could explain the disappearance of icebergs in the $10-50 \mathrm{~m}$ size category. If melting and calving were dramatically higher, and therefore able to account for the decreasing numbers of larger icebergs, one could expect to see a change in the shape of the frequency distribution for each longitude zone between long. $90^{\circ}$ and $120^{\circ} \mathrm{E}$. Figure 7 demonstrates that this is not so.

The grouping of iceberg observations into categories which vary in range from $40 \mathrm{~m}$ (e.g. $10-50 \mathrm{~m}$ category) to more than $500 \mathrm{~m}$ (e.g. $500-1000 \mathrm{~m}$ category) calls into question the possibility of statistical bias. Figure 7 shows a comparison between the average cumulative frequency distribution and the previous compilation of Budd and others (1980, fig. 7), which included the distributions of Romanov (1973). Note that the Budd and others (1980) compilation only considered icebergs above $50 \mathrm{~m}$; therefore, to be consistent, the same cut-off is adopted. Close agreement is apparent (in Fig. 7) between our data and the frequency distribution of Budd and others (1980) for non-tabular icebergs. This would indicate that the smaller sampling range for the smaller-sized icebergs does not bias the

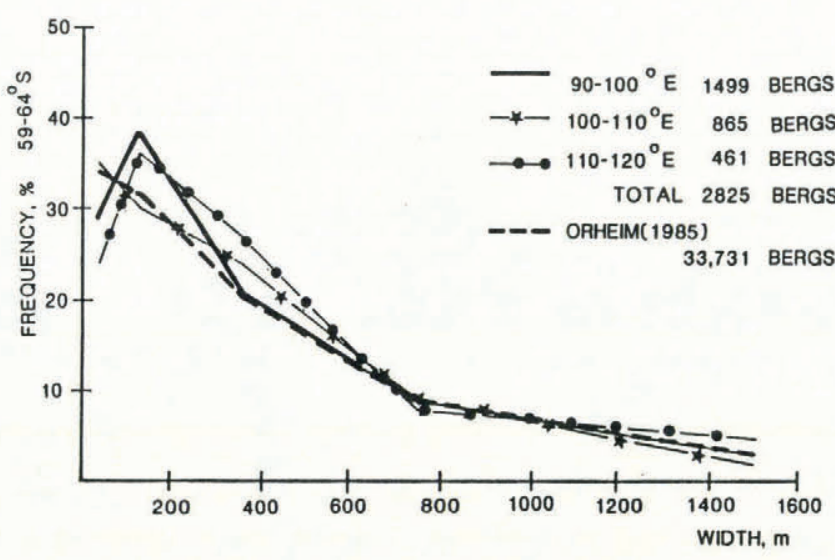

Fig. 6. Size-frequency distribution for the study area between lat. $59^{\circ}$ and $64^{\circ} \mathrm{S}$., for each of three sectors of longitude: $90^{\circ}$ to $100^{\circ} \mathrm{E}$. (with 1499 icebergs classified by size), $100^{\circ}$ to $110^{\circ} \mathrm{E}$. (with 865 icebergs classified by size), $110^{\circ}$ to $120^{\circ} \mathrm{E}$. (with 461 icebergs classified by size). Note the dashed line which represents the International Data Base covering 33731 icebergs classified by size (Orheim, 1985; between 1981 and 1984).

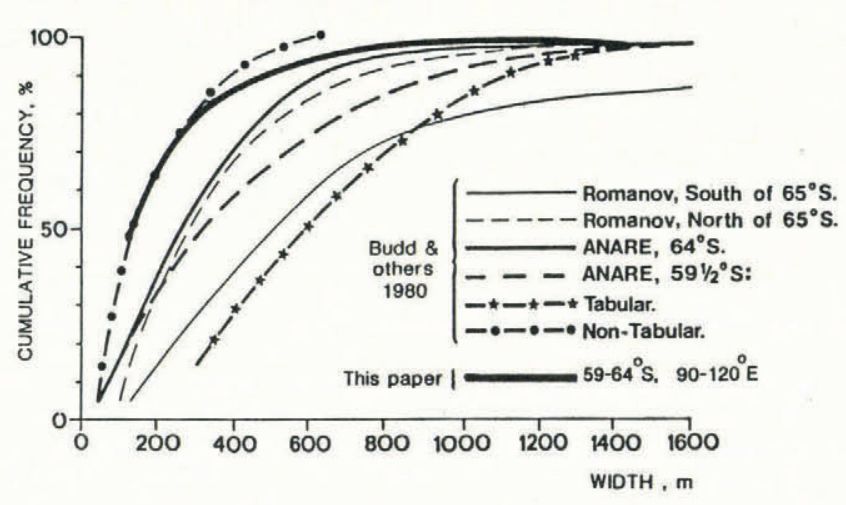

Fig. 7. The average cumulative frequency distribution from Figure 6 of this paper (shown as the thick solid line, lat. $59^{\circ}$ to $64^{\circ} \mathrm{S}$., and long. $90^{\circ}$ to $120^{\circ} \mathrm{E}$.), in comparison with figure 7 of Budd and others (1980). Note that this representation only applies to icebergs greater than $50 \mathrm{~m}$ in width.

frequency distribution, since the data used by Budd and others (1980) came from earlier records of individual iceberg sightings and are not subject to categorization in variable size ranges.

Figure 8 represents the iceberg concentration as a function of size for each of the longitude bands, $90-100^{\circ} \mathrm{E}$., $100-110^{\circ} \mathrm{E}$., and $110-120^{\circ} \mathrm{E}$. As was shown in Figure 6 , the approximate doubling in concentration as the size factor halves (except for icebergs in the smallest category of $10-50 \mathrm{~m}$ ) is evidence supporting, in principle, the breakage theory of Budd and others (1980), provided a volume loss from small fragments formed during breakage is taken into account. Furthermore, the similarity in the shape of the distributions indicates that the breakage rate for different sizes cannot be substantially different. The uncertainty in our estimates of the volume loss, however, makes the mathematical description more complicated.

Analysis of the data shown in Figure 8 led to the determination of the averge dissolution rate and therefore the calculation of the iceberg median life before breakage for the different size ranges. Calculations suggest that, for icebergs less than $1000 \mathrm{~m}$ in width, a "median life" of 0.2 year should be regarded as a close approximation, irrespective of exact size or shape. Detailed numerical modelling (which is beyond the scope of this paper), in conjunction with slightly modified field data (e.g. size groupings which exactly double in size along with more 


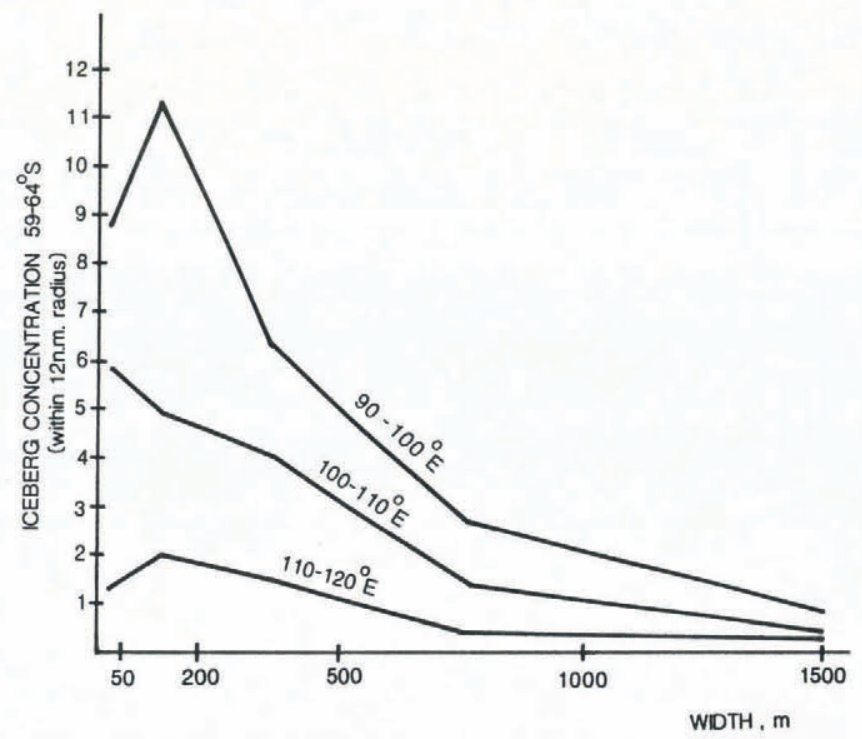

Fig. 8. Concentration of iceberg sizes (within a 12 nautical mile radius) for the lat. $59^{\circ}$ to $64^{\circ} \mathrm{S}$. study area between long. $90^{\circ}$ to $100^{\circ} \mathrm{E}$., $100^{\circ}$ to $110^{\circ} \mathrm{E}$., and $110^{\circ}$ to $120^{\circ} \mathrm{E}$.

height, width, and thickness detail, especially for tabular icebergs), will be required to refine these estimates with respect to size.

What is clear (Fig. 8) is that melt is able to explain the disappearance of most icebergs in the $10-50 \mathrm{~m}$ category within the estimated 3.5 month time interval that it takes to travel a $10^{\circ}$ sector of longitude. The melt rate is thus estimated from the time required to melt half of the mean dimension of the smallest category where the frequency distribution appears to level out, i.e. $(35-10) / 2=12.5 \mathrm{~m}$ in $107 \mathrm{~d}=0.12 \mathrm{~m} \mathrm{~d}^{-1}$. This agrees generally with the laboratory melt rates of approximately $0.1 \mathrm{~m} \mathrm{~d}^{-1}$ at water temperatures of $+1{ }^{\circ} \mathrm{C}$ (Russell-Head, 1980) and the assessment of Neshyba and Josberger (1980). Robe and others (1977), however, have photographed an Arctic iceberg (approximate dimensions $725 \mathrm{~m} \times 300 \mathrm{~m} \times 30 \mathrm{~m}$ ) which showed a horizontal melt rate of approximately $1.5 \mathrm{~m} \mathrm{~d}^{-1}$ for a typical surface water temperature between $+2^{\circ}$ and $+4^{\circ} \mathrm{C}$. In summer, it is possible for the top $50 \mathrm{~m}$ to reach $+2{ }^{\circ} \mathrm{C}$ (Budd and others, 1980, fig. 14), which could cause more rapid melting especially of the smaller icebergs. Note that, during winter months, water temperatures of below zero could be expected and melt rates must be much less. Such variability is, however, outside the scope of the present study.

\section{ICEBERG-DISSOLUTION PROCESSES}

Certain dissolution processes are fairly clear, having been observed in practice and explained theoretically (e.g. the fracture of large relatively thin tabular icebergs (Goodman and others, 1980)). Other effects are at least plausible even if not observed in practice, for example, that iceberg-breakage rates decline as icebergs become blocky (i.e. when length, breadth, and thickness are all similar). Blocky icebergs tend to roll over on a repeated basis, exposing jagged corners or edges forming the pinnacles of blue-ice characteristic of medium to small icebergs (i.e. less than $600 \mathrm{~m}$ in width).

The action of submarine melting tends to cause smoothing of the under-water shape; however, the extraordinary height of pinnacles revealed by roll-over implies that breakage is still a feature in the dissolution process of smaller icebergs.

Calving around the edges due to wave action might appear to be a major dissolution mechanism, especially for larger tabular icebergs. However, these visually spectacular events have been observed to contribute less to the dissolution process than submarine melting (Keys and Williams, 1984). Wave action is an effective mechanism in eroding the low-density, upper firn layers, resulting in an "avalanche-like" collapse of side walls. However, the firn component so removed is a very small part of the overall mass of a tabular iceberg and, once removed, the same wave action has a much less aggressive effect on the blueice side walls of pinnacled icebergs.

A more complete description of these processes can be found in Budd and others (1980).

Figure 9 shows a sample of results for typical iceberg height or freeboard versus width. Note that the pinnacled

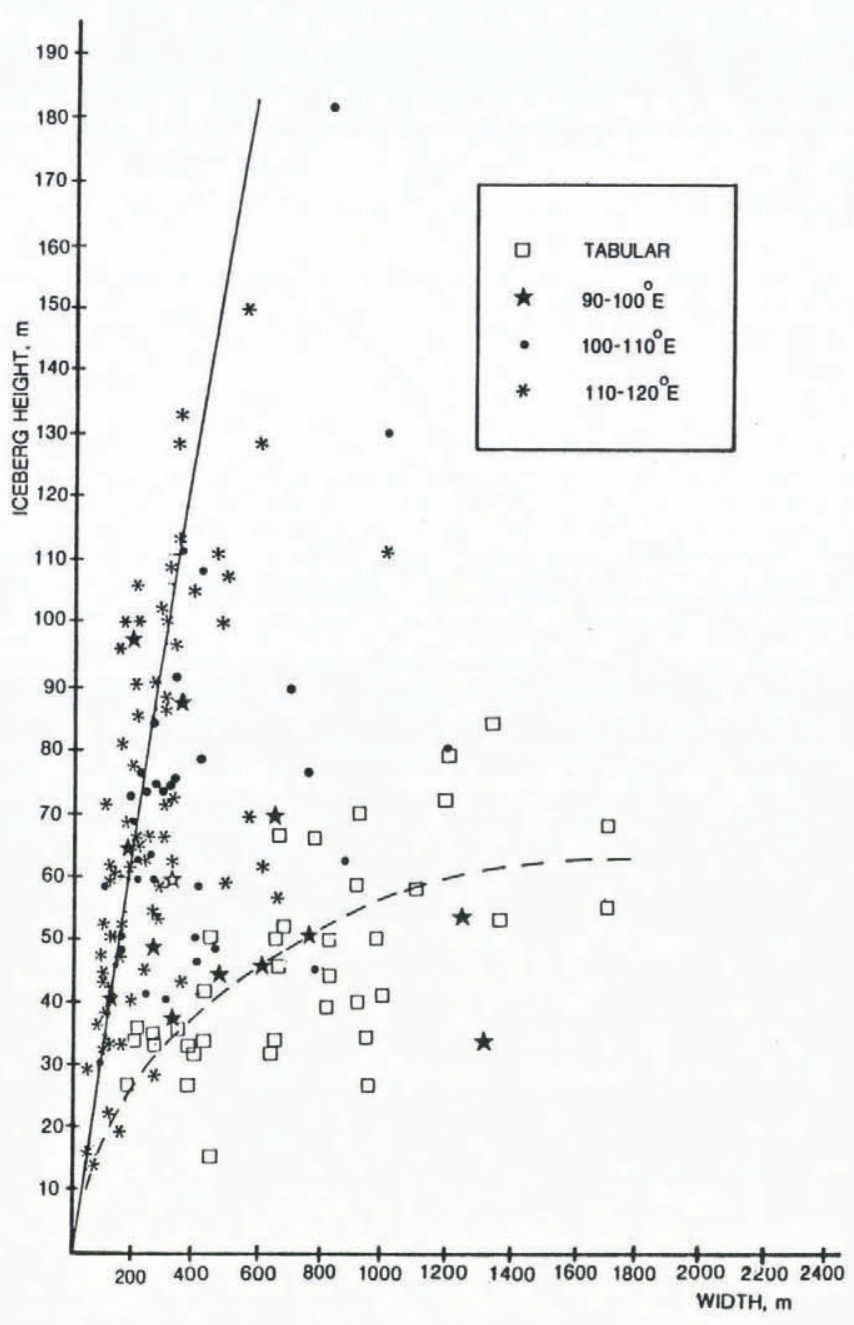

Fig. 9. Sample of results of iceberg height (or freeboard) to width. The solid line is typical of pinnacled or irregular icebergs while the dashed line represents tabular icebergs. Note that the open squares represent tabular icebergs only (from observations to 1977), whereas the other points for various longitude bands are irrespective of shape.

icebergs seem to have an upper limit in width of about $600 \mathrm{~m}$. The open squares, which are for tabular icebergs only, show that the average freeboard tends towards an upper limit of about $60 \mathrm{~m}$ for icebergs greater than $1500 \mathrm{~m}$ in length.

Most icebergs in the $200-500 \mathrm{~m}$ category and smaller are subject to roll-over, which effectively increases the vertical melt rate by about 50\% (Budd and others, 1980). Whereas, for tabular icebergs a height to thickness ratio of 1 : 7 (Shabtaie and Bentley, 1982) is typical, for pinnacled icebergs a height (measured to the average top of the peaks) to thickness ratio of $1: 2$ or 3 is more likely. Table I shows the estimated thickness and average height/freeboard for the various size categories.

It is quite apparent that the breakage mechanism results in overall volume loss. In other words, the volume of the 
TABLE I. PHYSICAL CHARACTERISTICS OF ANTARCTIC ICEBERGS

$\begin{array}{lccccc}\text { Size category }(\mathrm{m}) & 10-50 & 50-200 & 200-500 & 500-1000 & \text { over } 1000 \\ \text { Height }(\mathrm{m}) & 10 & 20(-60) & 35(-100) & 50 & 60 \\ \text { Estimated thickness }(\mathrm{m}) & 20 & 90 & 200 & 300 & 400 \\ \text { Length to breadth ratio } & 1.4: 1 & 1.4: 1 & 1.5: 1 & 2: 1 & 3: 1 \\ \begin{array}{l}\text { Volume per iceberg } \\ \left(\mathrm{m}^{3} \times 10^{6}\right)\end{array} & 0.02 & 1.3 & 17.5 & 84.4 & 300.0 \\ \begin{array}{l}\text { Percentage by count } \\ \text { Percentage by volume }\end{array} & 28 & 36 & 24 & 8 & 4\end{array}$

major pieces is significantly less than the volume of the original iceberg before breakage occurred. This can be inferred from the iceberg numbers and sizes (or volumes) given in Figure 4 and Table $I$. It is concluded that breakage is probably accompanied by the formation of a significant quantity of smaller pieces which disappear quickly.

\section{DISCUSSION}

The interpretation of iceberg concentrations from shipboard observations requires some care. For example, the horizon (or range) applicable to visual sightings depends on the elevation of the observer above sea-level. Obviously, this elevation in turn depends on the ship (and size of iceberg, if it is beyond the horizon). In general, irrespective of the observer's exact elevation, the number of icebergs in the smallest size category will be slightly underestimated (at higher southerly latitudes) since, at the maximum range they may be impossible to see. On the other hand, at more northerly latitudes (e.g. between lat. $50^{\circ}$ and $58^{\circ} \mathrm{S}$., from long. $60^{\circ}$ to $120^{\circ} \mathrm{E}$.), lower iceberg concentrations (especially for the smaller size categories) may be slightly overestimated. For example, when the first icebergs are encountered, logbook records might show a concentration of one iceberg within a $12 \mathrm{n} . \mathrm{m}$. radius, yet it may be several hours (or even days) or degrees of latitude before more icebergs are observed, i.e. one iceberg might be more typical of a 100 n.m. radius, and thus the concentration per $12 \mathrm{n} . \mathrm{m}$. radius is, in theory, less than one. Therefore, at the northern iceberg boundary, concentrations may appear artificially high unless allowance is made for "no sightings" of icebergs (in the spatial domain).

Iceberg-height data used in this paper were obtained from sextant and radar measurements (as previously described). However, the amount of data is limited and requires more attention in future studies. Icebergs in the smallest category $(10-50 \mathrm{~m})$ with a height of less than $5 \mathrm{~m}$ are normally ignored (because in theory they do not qualify as icebergs) and this leads to the, perhaps surprising, result that such icebergs have an average height of $10 \mathrm{~m}$ (as shown in Table I) for an estimated thickness of about $20 \mathrm{~m}$.

Determination of iceberg-dissolution rates, using the statistical analysis of Budd and others (1980), has revealed that Antarctic icebergs seem to change from large to small at a rate which is much faster than previously thought. These calculations lend credence to the general observation of Orheim (1980), who suggested that "many icebergs do not survive two months in the open sea".

Additionally, there is the indirect evidence of iceberg dissolution from the drift track records of Tchernia and Jeannin $(1980,1984)$. It is interesting to note that icebergs which were tracked in the Enderby Land and Terre Adelie region, irrespective of their exact size or thickness, were all lost after about 11 months (e.g. Tchernia and Jeannin, 1984; iceberg No. 49 (length) $3800 \mathrm{~m} \times$ (width) $1000 \mathrm{~m} \times$ (height) $50 \mathrm{~m}=11$ months; iceberg No. $1061,1200 \mathrm{~m} \times 400 \mathrm{~m} \times$ $27 \mathrm{~m}=11$ months; iceberg No. $1062,900 \mathrm{~m} \times 300 \mathrm{~m} \times$ $36 \mathrm{~m}=9$ months; iceberg No. $1063,800 \mathrm{~m} \times 400 \mathrm{~m} \times 35 \mathrm{~m}$ $=12$ months; iceberg No. $18,500 \mathrm{~m} \times 350 \mathrm{~m} \times ? ? ? \mathrm{~m}$
$=11$ months; iceberg No. $211,400 \mathrm{~m} \times 220 \mathrm{~m} \times 25 \mathrm{~m}=11$ months; iceberg No. $474,1400 \mathrm{~m} \times ? ? ? \mathrm{~m} \times 25 \mathrm{~m}=15$ months).

Most of the transponders (for icebergs in this region) were deployed by the ANARE and it was difficult to find suitable large regular-shaped icebergs with little evidence of crevassing or internal weakness. It is therefore reasonable to assume that icebergs which were tracked would be likely to survive much longer than the average (for whichever size group). Cessation of signals from the transponder may have been caused by a power-supply failure or instrumentation problem; however, this is unlikely given the proven reliability of the transponders and that the batteries should have lasted for several years (Laclavère, 1973). In fact, Tchernia (personal communication) agrees that "the cessations being all in summer, whatever the region, indicate the cause to be dissolution of the icebergs, rather than failure of the electronics". A mean iceberg median-life of 0.2 year, therefore, is still consistent with the typical transponder life time of 12 months. For example, after five "median-life" periods of 0.2 year ( 12 months), approximately $3 \%$ of the original sample could be expected to remain intact. It is reasonable, therefore, to assume that icebergs (especially those which have been carefully selected for tracking) are able to survive for around 12 months, with or without major breakage, before transponder signals cease, presumably as a result of roll-over.

It is suggested that for icebergs, in the size range $500-1000 \mathrm{~m}$ or greater, roll-over is a relatively rare event (generally these icebergs are tabular). If, then, after one or more breakage events, the pieces fall into the size ranges of $200-500 \mathrm{~m}$ or smaller, roll-over (because of the fact that the thickness is now similar to or greater than width) becomes a common event. Once the transponder hits the water, as a result of roll-over, it ceases to function.

Table I summarizes current estimates for the physical characteristics of Antarctic icebergs as used in this paper. It is interesting to note that, although icebergs greater than $1000 \mathrm{~m}$ in width constitute only $4 \%$ by count, they comprise $51 \%$ of the total iceberg volume in the Southern Ocean between long. $60^{\circ}$ and $130^{\circ} \mathrm{E}$. Such percentages are only approximate and are of course affected by sightings (or non-sightings) of gigantic icebergs. Gigantic icebergs are known to exist in this region but are rarely seen or recorded in shipboard logs.

Table II shows that the total volume of ice (which is at a maximum in the sector between long. $90^{\circ}$ and $100^{\circ}$ E.) decreases to about half with each successive $10^{\circ}$ segment to the east. The disappearing iceberg volume is thus a direct measurement of one source of fresh-water input into the ocean in these areas.

\section{COMPARISON WITH THE OBSERVATIONS OF CAPTAIN JAMES COOK IN 1773}

Part of Captain James Cook's plan for his second voyage (1772-75), sponsored by the British Board of Longitudes) involved the further search at high southern latitudes (about lat. $60^{\circ} \mathrm{S}$.) for the speculated although still undiscovered southern continent (Antarctica). 
TABLE II. ICEBERG VOLUME PER 12 NAUTICAL MILE RADIUS $\left(=1550 \mathrm{~km}^{2}\right)$ CALCULATED FROM THE PRODUCT OF ICEBERG CONCENTRATION (FIG. 8) AND VOLUME PER ICEBERG (TABLE I). TOTAL ICEBERG VOLUME PER $10^{6}$ LONG. REPRESENTS THE SUM OF THE PRODUCTS FOR EACH SIZE CATEGORY, AS SHOWN, FROM LONG. $90^{\circ}$ TO $130^{\circ} \mathrm{E}$.

\begin{tabular}{ccrcrcr}
$\begin{array}{c}\text { Longitude } \\
\text { segment } \\
\text { E. }\end{array}$ & \multicolumn{3}{c}{$\begin{array}{c}\text { Size category } \\
\mathrm{m}\end{array}$} & & & $\begin{array}{c}\text { Total iceberg } \\
\text { volume } \\
\mathrm{m}^{3} \times 10^{6}\end{array}$ \\
& $10-50$ & $50-200$ & $200-500$ & $500-1000$ & over 1000 & \\
$90-100$ & 0.2 & 14.7 & 111.3 & 227.9 & 264.0 & 618.1 \\
$100-110$ & 0.1 & 6.4 & 70.7 & 121.5 & 120.0 & 318.7 \\
$110-120$ & 0.03 & 2.6 & 26.3 & 36.3 & 72.0 & 137.2 \\
$120-130$ & - & 1.0 & 27.8 & 4.2 & 42.0 & 75.0
\end{tabular}

While also searching, unsuccessfully, for what is now known as Archipel de Kerguelen, Cook's ship Resolution became separated from the sister ship, Adventure, commanded by Captain Tobias Furneaux. This occurred on 8 February 1773 at lat. $49^{\circ} 51^{\prime} \mathrm{S}$., long. $63^{\circ} 57^{\prime} \mathrm{E}$. (Eventually, both ships were to rendezvous in Queen Charlotte's Sound, New Zealand, Adventure arriving 6 weeks in advance of Resolution.) In the meantime, however, Cook proceeded south as far as lat. $61^{\circ}$ to $62^{\circ} \mathrm{S}$. (long. $\sim 95^{\circ} \mathrm{E}$.), being as far as "ice and prudence" (Cook's letter to $\mathrm{Mr}$ John Walker of 14 September 1775 (from Beaglehole, 1961)) would allow. The route of Resolution and Adventure is shown in Figure 4 with asterisks indicating days on which icebergs were observed.

Cook's journal rarely mentions actual iceberg concentrations (other than by referring to the terms, many, several, or few) and usually refers to the total number of icebergs sighted during the course of the day. However, on several occasions, records are clear on the number visible at any one time (shown by asterisks in Figures 1 and 2). Although the deck was approximately $6 \mathrm{~m}$ from water-level, it is reasonable to assume a similar visible horizon from the crow's nest, as from the bridge of ships used in contemporary ANARE observations. Unfortunately, it is not known at what exact height above sea-level these earlier observations were made. Nevertheless, Cook's iceberg concentrations not only conform well with the modern ANARE observations but so also does the approximate northerly limit of iceberg sightings.

After losing contact with Adventure, Cook again encountered the northerly limit of icebergs on 24 February 1773 at lat. $57^{\circ} 08^{\prime} \mathrm{S}$., long. $80^{\circ} 59^{\prime} \mathrm{E}$. From then until 8 March 1773 at lat. $59^{\circ} 44^{\prime} \mathrm{S}$., long. $102^{\circ} 44^{\prime} \mathrm{E}$., iceberg sightings were regular and usually described as being "several" or "many". During this period, the days on which iceberg sightings were not recorded usually coincided with foggy or wet weather, accounting for a lack of visibility.

Thus, while Cook was sailing inside the northerly edge of icebergs in this region of the Southern Ocean, Captain Furneaux (in Adventure, and mostly sailing between lat. $52^{\circ}$ and $53^{\circ} \mathrm{S}$;; Fig. 4) recorded in his journal upon arriving in New Zealand "... and what is remarkable we have seen but one island of ice since we parted company witn the Resolution till our making of land, tho' we were mostiy two or three degrees to the southward of the latitude we first saw them in."

The records of Cook and Furneaux more than 200 years ago therefore seem to be in general accordance with contemporary iceberg distributions (as shown in Figures 1 and 2). During Cook's voyage, iceberg breakage was also observed and described. The following passage is extracted from the journal of William Wales (Wales and Bayly, 1777), astronomer to Captain Cook in HMS Resolution 1772-75: "... Many islands of ice. One in particular, which we passed in the afternoon, was near a mile and a half long, and very high. It was calm most part of the night, so that we found ourselves very near it in the morning, but observed that several very large pieces had broke off it. Many great rapports, like thunder, were heard in the night, which I conceive to be these pieces breaking off. An almost universal dissolution began, about this time, to take place among these vast, and, to us, tremendous bodies of frigid matter". And, again, from the notes of William Wales (extracted from Beaglehole (1961)): "... About $19^{\text {h }}$ a very large island of ice burst in an instant into 3 large, and many small pieces just as we came a breast of it. It made no report or at least so little, that we could not hear it for the noise of the sea and $\mathrm{y}^{\mathrm{e}}$ whistling of $\mathrm{y}^{\mathrm{e}}$ wind in the rigging."

\section{CONCLUSIONS}

In the region of East Antarctica between long. $60^{\circ}$ and $140^{\circ} \mathrm{E}$., iceberg concentrations increase with distance south, in all size categories from less than one iceberg per $12 \mathrm{n} . \mathrm{m}$. radius (north of lat. $59^{\circ} \mathrm{S}$.) to a local maximum at a latitude near the edge of the continental shelf. Iceberg concentrations then show a decrease corresponding to the Antarctic Divergence before increasing to a peak near the Antarctic coast.

Although icebergs are observed in waters north of lat. $58^{\circ} \mathrm{S}$., these occurrences appear to be infrequent and sporadic.

Qualitative correspondence is observed between the effective extent of iceberg observations (approximately lat. $59^{\circ} \mathrm{S}$.) and the maximum extent of Antarctic sea ice in this region. For this ocean region off East Antarctica, between long. $60^{\circ}$ and $130^{\circ} \mathrm{E}$., iceberg sightings north of the Antarctic Convergence (approximately lat. $51^{\circ} \mathrm{S}$.) are rare. Those sighted appear to be the remnants of very large icebergs and are generally smaller than $200 \mathrm{~m}$ in horizontal dimension.

Statistical analysis of icebergs in a study area situated in the circum-polar flow region (between lat. $59^{\circ}$ and $64^{\circ} \mathrm{S}$, and in $10^{\circ}$ sectors of longitude between long. $90^{\circ}$ and $120^{\circ} \mathrm{E}$.) has resulted in the classification by size of 2825 icebergs. Frequency distributions for these sectors show close agreement with those from the International Data Base (Orheim, 1985) which includes 33731 icebergs classified by size.

Breakage, with associated volume wastage from the production of small pieces, appears to be the principal mechanism in the dissolution process. As icebergs break down into smaller-sized pieces, however, the action of melt (and calving) becomes more dominant such that the disappearance of icebergs between 10 and $50 \mathrm{~m}$ in width (within a 3.5 month period) could be wholly accounted for by sub-surface melting.

The median life (before breakage or roll-over) of Antarctic icebergs (in this region) which are less than $1000 \mathrm{~m}$ in width is estimated to be $0.2 \mathrm{a}$. This estimate is much less than was previously thought and may be a feature of icebergs drifting in the Circum-polar Current and not necessarily applicable to regions closer to the coast.

The melt rate of Antarctic icebergs (for a mean water temperature of $+1{ }^{\circ} \mathrm{C}$ ) is estimated to be $0.12 \mathrm{~m} \mathrm{~d}^{-1}$.

Repeated roll-over may be expected to occur for the majority of icebergs less than about $300 \mathrm{~m}$ in horizontal dimension.

The analysis of iceberg observations made by Cook (near lat. $60^{\circ} \mathrm{S}$.) and Furneaux (near lat. $53^{\circ} \mathrm{S}$.) between long. $80^{\circ}$ and $130^{\circ} \mathrm{E}$., during 1773 , shows similar concentrations to those obtained from the modern data. However, the limited sample for earlier data only allows the 
conclusion that the iceberg distribution observed in this region 200 years ago is compatible with the distribution determined in recent years.

\section{ACKNOWLEDGEMENTS}

The process of collecting data on iceberg observations during ANARE voyages has been undertaken, of ten anonymously, by a wide variety of expeditioners. The authors are grateful to all of those who have assisted and hope that publication of a paper such as this is of some reward and mutual benefit.

Furthermore, we hope to encourage the continuation of diligent iceberg observations in the future, in the knowledge that the data are of real and practical importance.

Special thanks are due to $\mathrm{Mr}$ T.H. Jacka for organizing the distribution and collection of iceberg logbooks. Thanks are also due to $\mathrm{L}$. Christou for keying-in the data to a computer file, and Mrs V. Murphy for typing of the text. The constructive criticism of $\mathrm{Mr}$ I. Allison is also acknowledged, and has been instrumental in moulding this paper into a more meaningful presentation.

\section{REFERENCES}

Beaglehole, J.C., ed. 1961. The journals of Captain James Cook on his voyages of discovery. The voyage of the Resolution and Adventure, 1772-1775. Cambridge, Hakluyt Society at the University Press.

Bruneau, A.A., and others. 1978. Iceberg towing for oil rig avoidance, by A.A. Bruneau, R.T. Dempster, and G.R. Peters. (In Husseiny, A.A., ed. Iceberg utilization. Proceedings of the First International Conference and Workshops on Iceberg Utilization for Fresh Water Production, Weather Modification, and Other Applications, held at Iowa State University, Ames, Iowa, U.S.A., October 2-6, 1977. New York, etc., Pergamon Press, p. 379-88.)

Budd, W.F., and others. 1980. Antarctic iceberg melt rates derived from size distributions and movement rates, by W.F. Budd, T.H. Jacka, and V.I. Morgan. Annals of Glaciology, Vol. 1, p. 103-12.

Burrows, C.J. 1976. Icebergs in the Southern Ocean. New Zealand Geographer, Vol. 32, No. 2, p. 127-38

Dmitrash, Zh. A. 1971. O nekotorykh osobennostyakh raspredeleniya aysbergov $v$ Vostochnoy Antarktike. [Some characteristics of iceberg distribution in the eastern Antarctic]. Sovetskaya Antarkticheskaya Ekspeditsiya. Informatsionnyy Byulleten', No. 82, p. 37-41.

Goodman, D.J., and others. 1980. The flexural response of a tabular ice island to ocean swell, by D.J. Goodman, P. Wadhams, and V.A. Squire. Annals of Glaciology, Vol. 1, p. 23-27.

Gordon, A.L., and Goldberg, R.D. 1970. Circumpolar characteristics of Antarctic waters. New York, American Geographical Society. (Antarctic Map Folio Series, Folio 13.)

Husseiny, A.A., ed. 1978. Iceberg utilization. Proceedings of the First International Conference and Workshops on Iceberg Utilization for Fresh Water Production, Weather Modification, and Other Applications held at Iowa State University, Ames, Iowa, U.S.A., October 2-6, 1977. New York, etc., Pergamon Press.

International Glaciological Society. 1980. Proceedings of the Conference on Use of Icebergs: Scientific and Practical Feasibility, Cambridge, UK, 1-3 April 1980. Annals of Glaciology, Vol. 1.

Jacka, T.H. 1983. A computer data base for Antarctic sea ice extent. ANARE Research Notes, No. 13.

Keys, J.R. 1984. Antarctic marine environment and offshore oil. Wellington, New Zealand, Commission for the Environment.

Keys, J.R., and Williams, K.L. 1984. Rates and mechanisms of iceberg ablation in the D'Urville Sea, Southern Ocean. Journal of Glaciology, Vol. 30 , No. 105, p. 218-22.

Laclavère, G.R. 1973. The Eole-Iceberg programme. Polar Record, Vol, 16, No. 104, p. 764-68.

McClain, E.P. 1978. Eleven year chronicle of one of the world's most gigantic icebergs. Mariners Weather Log, Vol. 22 , No. 5 , p. $328-33$.
Morgan, V.I., and Budd, W.F. 1978. The distribution, movement and melt rates of Antarctic icebergs. (In Husseiny, A.A., ed. Iceberg utilization. Proceedings of the First International Conference and Workshops on Iceberg Utilization for Fresh Water Production, Weather Modification, and Other Applications, held at Iowa State University, Ames, Iowa, U.S.A., October 2-6, 1977. New York, etc., Pergamon Press, p. 220-28.)

Nazarov, V.S. 1962. L'dy Antarkticheskikh vod. [Ice in Antarctic waters]. Rezul'taty Issledovaniy po Mezhdunarodnym Geofizicheskim Proyektam. Okeanologiya, No. 6.

Neshyba, S. 1980. On the size distribution of Antarctic icebergs. Cold Regions Science and Technology, Vol. 1, Nos. 3-4, p. 241-48.

Neshyba, S., and Josberger, E.G. 1980. On the estimation of Antarctic iceberg melt rate. Journal of Physical Oceanography, Vol. 10, No. 10, p. 1681-85.

Orheim, O. 1980. Physical characteristics and life expectancy of tabular Antarctic icebergs. Annals of Glaciology, Vol. 1, p. 11-18.

Orheim, O. 1985. Iceberg discharge and the mass balance of Antarctica. (In Glaciers, ice sheets, and sea level: effect of a $\mathrm{CO}_{2}$-induced climatic change. Report of a workshop held in Seattle, Washington, United States, September 13-15, 1984. Washington, DC, Department of Energy, p. 210-15.)

POAC. 1979. POAC 79. Proceedings of The Fifth International Conference on Port and Ocean Engineering under Arctic Conditions. At the Norwegian Institute of Technology, August 13-18, 1979. Proceedings. Trondheim, University of Tromsø/Norwegian Institute of Technology.

Robe, R.Q. 1980. Iceberg drift and deterioration. (In Colbeck, S.C., ed. Dynamics of snow and ice masses. New York, Academic Press, p. 211-59.)

Robe, R.Q., and others. 1977. Iceberg deterioration, by R.Q. Robe, D.C. Maier, and R.C. Kollmeyer. Nature, Vol. 267, No. 5611, p. 505-06.

Romanov, A.A. 1973. O razmerakh aysbergov v Vostochnoy Antarktike. [The size of icebergs in eastern Antarctica]. Sovetskaya Antarkticheskaya Ekspeditsiya. Informatsionnyy Byulleten', No. 87.

Russell, W.E., ed. 1979. Iceberg Dynamics Symposium, June 4 and 5, 1979, St. John's, Newfoundland, Canada. Cold Regions Science and Technology, Vol. 1, Nos. 3-4, p. 167-306.

Russell-Head, D.S. 1980. The melting of free-drifting icebergs. Annals of Glaciology, Vol. 1, p. 119-22.

Schwerdtfeger, P. 1978. Weather modification and environmental and ecological impact (caused by towing icebergs) - a workshop discussion. (In Husseiny, A.A., ed. Iceberg utilization. Proceedings of the First International Conference and Workshops on Iceberg Utilization for Fresh Water Production, Weather Modification, and Other Applications, held at Iowa State University, Ames, Iowa, U.S.A., October 2-6, 1977. New York, etc., Pergamon Press, p. 713-15.)

Schwerdtfeger, P. 1979. Review. On icebergs and their uses; a report to the Australian Academy of Science. Cold Regions Science and Technology, Vol. 1, No. 1, p. 59-79.

Shabtaie, S., and Bentley, C.R. 1982. Tabular icebergs: implications from geophysical studies of ice shelves. Journal of Glaciology, Vol. 28, No. 100, p. 413-30.

Shilnikov, V.I. 1969. Aysbergi. [Icebergs]. (In Tolstikov, Ye. I., ed. Atlas Antarktiki II. [Atlas of the Antarctic II]. Leningrad, Gidrometeorologicheskoye Izdatel'stvo, p. 455-65.)

Shulenberger, E. 1983. Water-column studies near a melting Arctic iceberg. Polar Biology, Vol. 2, No. 3, p. 149-58.

Smith, N.R., and others. 1985. Water masses and circulation in the region of Prydz Bay, Antarctica, by N.R. Smith, Dong Zhaoqian, K.R. Kerry, and S. Wright. Deep Sea Research, Vol. 31A, No. 9, p. 1121-47.

Swithinbank, C., and others. 1977. Drift tracks of Antarctic icebergs, by C. Swithinbank, P. McClain, and P. Little Polar Record, Vol. 18, No. 116, p. 495-501.

Tchernia, P., and Jeannin, P.F. 1980. Observations on the Antarctic East Wind Drift using tabular icebergs tracked by satellite Nimbus $F$ (1975-1979). Deep Sea Research Vol. 27A, No. 6., p. 467-74. 
Hamley and Budd: Antarctic iceberg distribution and dissolution

Tchernia, P., and Jeannin, P.F. 1984. Quelques aspects de la circulation océanique Antarctique révélés par l'observation de la dérivé d'icebergs (1972-83). Paris, Muséum National d'Histoire Naturelle.

USSR. 1974. Batimetricheskaya karta Antarktiki. [Bathymetric map of Antarctica]. Moskva, Glavnoye Upravleniye Geodesiya i Kartografiya pri Sovete Ministrov.

Vinje, T.E. 1980. Some satellite-tracked iceberg drifts in the Antarctic. Annals of Glaciology, Vol. 1, p. 83-87.
Wales, W., and Bayly, W. 1777. The original astronomical observations made in the course of a voyage towards the South Pole, and round the world, in his Majesty's Ships the Resolution and Adventure in the years 1772, 1773. 1774 and 1775. London, J. Nourse, J. Mount and T. Page.

Weeks, W.F., and Campbell, W.J. 1973. Icebergs as a fresh-water source; an appraisal. Journal of Glaciology, Vol. 12 , No. 65 , p. 207-33.

MS. received 28 November 1985 and in revised form 23 April 1986 